\title{
A TURNING-POINT IN THE MINISTRY OF WOMEN: THE ORDINATION OF THE FIRST WOMAN TO THE CHRISTIAN MINISTRY IN ENGLAND IN SEPTEMBER 1917
}

\author{
bY ELAINE KAYE
}

7

HE modern debate about the ordination of women began in the early years of this century and has continued ever since. In the 1 course of that debate, the theology and practice of the Reformed churches are often ignored. This paper attempts to remedy that defect in part by discussing the context of the opening of the ordained ministry to women in this century.

The early movement for the ordination of women developed alongside both the suffragette movement and, in the Church of England particularly, the movement for more lay participation in church government. Brian Heeney charted this development in the Church of England both in his article on 'The beginnings of church feminism',' and in his recent posthumously-published book, The Women's Movement in the Church of England 1850-1930 (Oxford, 1988). In the latter he wrote, 'By 1916 advocacy of the priesthood for women had become a recognized part of the church feminist cause, and its champions were recognized as the avant-garde of that cause.' The Church League for Women's Suffrage, later renamed the League of the Church Militant, was founded in I909. The comparable Nonconformist organization, the Free Church League for Women's Suffrage, was already in existence by 1911 , and its journal The Free Church Suffrage Times, first issued in April I9 I 3, provided a forum not only for the advocacy of women's suffrage, but also for the advancement of women's participation in the life and ministry of the Nonconformist churches.

This paper considers, necessarily briefly, some of the ideas and achievements of four women who played a significant role in this movement: Gertrude von Petzold, a Unitarian, Hatry Baker and Constance Coltman (née Todd), both Congregationalists, and Maude Royden, who, although

1 B. Heeney, 'The beginnings of church feminism: women and the councils of the Church of England I 897-1919', JEH, 33 (1982), pp. 89-109.

2 B. Heeney, The Women's Movement in the Church of England 1850-1930 (Oxford, 1988), p. 127. 
an Anglican, exercised a preaching ministry in a Congregational church for a time. Of these, the greatest figure by far is Maude Royden, whose biography has just been published. ${ }^{3}$ The reason why I have chosen Constance Coltman, rather than Maude Royden-they were friends-as the central figure in this paper is that she was the first woman to be ordained to the Christian ministry by the authority of her denominarion, and, together with her husband, she exercised a pastoral ministry for some thirty years. ${ }^{4}$ Maude Royden remained faithful to the Anglican Church until the end of her life, and was therefore never given the opportunity of ordination.

Though women preachers were known in earlier centuries, the first woman to assume pastoral responsibility for a church in England in this century was Gertrude von Petzold. ${ }^{5}$ The daughter of a Prussian army officer, and clearly a woman of spirit and determination, she studied in Scotland for several years before being admitted as a full-time ministerial student at Manchester College, Oxford, in I 901 . At the end of her course in I 904 she was called to serve as minister of Narborough Road Free Christian (Unitarian) Church in Leicester. Here she ministered to a large congregation for four years until she went to the United States in 1908. The writer of an article in The Christian World (1 5 April I909) stated that it was 'prejudice' which drove her away. The author of the rather curious account of her Leicester ministry ${ }^{6}$ implies that it was protests against her autocratic manner with the church committee which led to her resignation. Whatever the reason, she spent two years in the United States (where there were already numerous women ministers) before returning to this country to minister at the Unitarian Church in Small Heath, Birmingham, from IgI I until I9Is. In I9Is problems arose about her citizenship and she had to return to Germany, where she was interned for a while. Her later career was in the United States, and from 1915 she disappears from all English records.

Undoubtedly she was an individual pioneer, who must have prepared the way for others, but there is no evidence of her connection with any

${ }^{3}$ S. Fletcher, Maude Royden: $A$ Life (Oxford, I989).

4 For further biographical details about Constance Coltman, see E. Kaye, 'Constance Coltman - a forgotten pioneer', Journal of the United Reformed Church History Society , 4, 2 (May 1988).

s For information about Gertrude von Petzold, see R. V. Holt, The Unitarian Contribution to Social Progress in England (London, I938); Essex Hall Yearbook (London, 1916); C. G. Bolam, Three Hundred Years 1662-1962: The Story of the Churches forming the North Midland Presbyterian and Unitarian Association (Nottingham, 1962); and The Inquirer, 2 July 1904, 5 June and 7 August I9I5.

- A. Clarke, The First Woman Minister (London, 1941). 


\section{A Turning-point in the Ministry of Women}

suffrage or church feminist movement, nor was her induction the result of any specific decision of principle on the part of a denominational council.

During the first decade of the twentieth century, a few women began to preach and perform other ministerial tasks in Congregational churches. One of the most prominent was Hatty Baker, who not only exercised a pastoral and preaching ministry, but also acted as secretary of the Free Church League for Women's Suffrage. When Mrs Louisa Martindale built a Congregational hall in Horsted Keynes in 1907, she invited Hatty Baker to share the ministry there with students from Hackney College. In an article in The Christian World (is April 1909), C. S. Bremner described a visit to Horsted Keynes a few months earlier:

1 went down tc Horsted Keynes on purpose to hear Miss Baker preach. She is a student, a woman of education, spirirually-minded, capable. Dressed in a black Geneva gown, cap and plain white collar, Miss Baker reverently conducted the devotions of the congregation. The sermon was thoughtful, carefully prepared, and left much that is practical and applicable to the conduct of life in the minds of her hearers. I was struck by the numbers of heads of families, who listened to those half-hour sermons with the closest attention. Miss Baker has baptized children, officiated at the communion-table, and on the very day of my visit, heads of households, women as well as men, were signing a requisition to allow marriages to be solemnised in this beautiful little church.

The occasion of that article was the discussion of Hatty Baker's position in the General Purposes Committee of the Council of the Congregarional Union in March 1909. The way had been prepared when women were admitted to the Congregational Union Assembly in 1892; in many churches they were already serving as deacons. On this occasion the Committee recommended to the Council that if a woman were to comply with the requirements of college training imposed on male candidates for the ministry, and if she were to receive a call to a specific congregation belonging to the Congregational Union, she should be accredited and her ordination recognized. (A later reference to this meeting hints that some of the more conservative participants believed that these stipulations were sufficiently stringent to leave them safe from ministering women.) ${ }^{7}$ This recommendation was passed as a resolution by the Council. ${ }^{8}$ But Hatty

7 The British Weekly, 4 Oct. 1917.

8 See The Christian World, 18 March 1909 and 4 Oct. 1917. 
Baker had not complied with the first requirement and evidently was unable to do so, and therefore her ministry continued to be unofficial. By the end of 1909 she was doing mission work in Brighton; and in 1917 she was acting as co-pastor of a church in Plymouth, and assuming the title 'Reverend'.'

There is no evidence of any contact or friendship between Hatty Baker and Constance Todd, but it is clear that Hatty Baker did much to prepare the way for Constance Todd's admission to Mansfield College. Hatty Baker had written to several theological colleges to ask whether women applicants would be admitted. The principals had all replied that not until such an application had been received would the appropriate committees come to a decision. When Constance Todd applied to Mansfield College in 1913, therefore, the question had already been raised but not yet answered.

Constance Todd was twenty-four when she approached Dr Selbie, Principal of Mansfield College, Oxford (which incidentally stands next door to Manchester College, where Gertrude von Petzold studied). She was already the equivalent of a graduate (women had not yet been formally admitted to degrees in Oxford) of Somerville College, Oxford. Dr Selbie was sympathetic-later he was to become a Vice-President of the Society for the Ministry of Women-but above all he was impressed by what he recognized as a genuine calling of the Spirit, and offered her a place on the three-year ministerial course.

At Mansfield she not only completed the course successfully, but met and became engaged to a fellow student, Claud Coltman. It was therefore a joint ministry with her future husband which she sought after finishing her course in 1916 .

Both she and her fiancé had been drawn by the preaching and liturgical experiments of W. E. Orchard at the King's Weigh House Church in London. Orchard, unusually, described himself as both a 'feminist' and as a 'catholic', and was an active supporter of the Free Church League for Women's Suffrage, and of the Society of Free Catholics. Constance Todd became a member of the church in January I9I7. At the time the members of the Weigh House were looking for a minister or ministers to work in its mission at Darby Street, in the East End of London, and gradually the idea developed that this young couple might be invited to tackle this difficult assignment; they received a formal invitation in July 1917, and accepred it. Negotiations were begun with the London Congregational Union, and plans made for the ordination service.

'Hatty Baker. 'An equal ministry', in The Coming Day (Jan. 1917). 


\section{A Tuming-point in the Ministry of Women}

The ordination took place on Monday 17 September 1917 . The Weigh House church meeting minutes record: 'This day Claud Coltman M.A. and Constance Mary Todd B.D. were solemnly ordained to the Holy Ministry by the laying on of hands and invocation of the Holy Ghost.' ${ }^{10}$ The presiding minister was Orchard, assisted by three fellow Congregational ministers. The preacher, Stanley Russell, referred to a new age 'travailing at the birth', 'one in which men and women will be in partnership.." The next day, Claud Coltman and Constance Todd were married in the same church.

Because of a technical complication relating to the constitution of the Darby Street Mission, it was not until October that the Congregational Union Assembly ratified its decision of eight years earlier that a woman who had undergone the full ministerial training and had received a call to minister to a specific congregation would be recognized, after ordination, as a fully ordained and accredited minister. ${ }^{12}$ Constance Coltman's name henceforward appeared in the Congregational Year Book among the list of ministers.

The day before Constance Coltman was ordained, Maude Royden began a two-year preaching ministry as assistant to Dr Ford Newton at the City Temple (Congregational) Church. The rwo women became friends, and remained so for the rest of their lives. Maude Royden was an outstanding preacher, advocate of women's suffrage, pacifist (until the Second World War), and writer. ${ }^{13}$ She frequently preached in Nonconformist churches, and in Anglican churches as much as she was allowed to (and occasionally in defiance of episcopal authority).

Though Maude Royden was never able to seek ordination, Constance Coltman spent her whole career as an ordained minister. But, we may ask-what was the nature of the ministry to which she had been ordained? She was brought up as a Presbyterian and attended Putney Presbyterian Church. This was one of those Presbyterian churches founded through the initiative of Scotrish émigrés in the late nineteenth century, not one of the many older English Presbyterian churches which had drifted towards Unitarianism. Presbyterian tradition laid more emphasis than that of other Nonconformists on church order. This, coupled with her admiration for

10 King's Weigh House Church Meering Minure Book 1916-26 (13 Sept. 1917) (at Dr Williams's Library).

"The Christian World, 20 Sept. 1917.

12 Sce The British Weekly, 4 Oct. 1917, for an account of the discussion.

13 See A. Maude Royden, $A$ Threefold Cord (London, 1948) for a short but fascinating autobiographical account. 
Orchard, who was fast developing a 'catholic' idea of priesthood, suggests that Constance Coltman had a 'higher' conception of ministry than some of her fellow Congregationalists. Correspondence in The Christian World just after her ordination gives some idea of the range of Congregational theories of ministry. ${ }^{14}$ The Coltmans as well as Orchard joined the Society of Free Catholics; Orchard was a prolific contributor to its journal, The Free Catholic, and Constance Coltman an occasional one. ${ }^{15}$ Orchard himself later became a Catholic priest. Constance Coltman did not follow him to Rome, but to the end of her life continued to be deeply grateful for his influence.

These pioneers of women's ministry made a particular contribution to the understanding of ministry. Hatry Baker gave a remarkable lecture (later published) on 'Women in the ministry' to the London branch of the Liberal Christian League at the King's Weigh House in I9I I. ${ }^{16}$ After explaining that she was frequently 'bombarded' with Pauline quotations by opponents of women's ministry, she showed herself equal to the situation with a careful exposition of Paul's teaching which demonstrated that he could be called in defence of women's ministry too. Her most significant suggestion was on the need for partnership in ministry: in every church with more than one minister, there should be at least one woman minister. In Plymouth, she was part of such a partnership. 'We surely need a woman as well as a man to interpret the heart of our Mother-Father God', she declared. ${ }^{17}$

Constance Coltman believed that women had a special contribution to make to ministry. She expressed this most clearly in a sermon preached to the Society for the Ministry of Women in 1938 at the King's Weigh House. ${ }^{18}$ She predicted that the ministry of the future would consist more and more of teams of specialist ministers, and believed that women would have a particular contribution to make to religious education, and to pastoral work with young families. In addition, she believed that a woman could better express sympathy and understanding for 'ordinary working people', especially if she was herself a mother; that her very existence would act as a valuable symbol of the equality of all human beings; and

14 The Cliristian World, 27 Sept. and i I Oct. 1917.

is Constance Coltman, 'Women and the priesthood', The Free Catholic, 5 (Oct. 1920), pp. 161-4; 'The need for women confessors', The Free Catholic, 6 (April 1921), pp. 66-8.

16 Hatty Baker, Women in the Ministry (London, 1911 ).

17 lbid., p. 47.

18 Constance Coltman, 'Women's kingdom', in D. P. Thomson, ed., Women in the Pulpit (London, 1944). 


\section{$A$ Turning-point in the Ministry of Women}

that she would strengthen the search for peace. She herself was a convinced pacifist, and a lifelong member of the Fellowship of Reconciliation. In their ministries, ${ }^{19}$ she and her husband shared the work according to their own particular gifts.

Maude Royden wrote The Church and Woman in 1924 . She believed that the subordination of women was based on the exaggerated value placed on physical strength. "Women, indeed, may truly claim that their progress in freedom involves at every point the question of moral power as the supreme governing power in the world'. ${ }^{20}$ Further, the acceptance of the service of women in the ministry of the Church would aid a proper value of the material, and thus a proper understanding of sacramental religion.

These pioneers stressed the significance of the vision of the Motherhood of God, and they saw the ministry of women as contributing to a more profound understanding not only of ministry/priesthood, but of the Divine Nature.

They paved a way which others have followed, though it has to be said that it is one thing to be called, qualified, and recognized as a minister, and another to find acceptance by a particular congregation. A small company of women entered the Congregational ministry over the next forty years. Since the Presbyterians and most Congregationalists united in 1972 to form the United Reformed Church, the number has increased considerably. ${ }^{21}$

A Baptist congregation first invited a woman to take pastoral charge in 1918 , and 'women pastors' were officially recognized in 1925 , but it was not until 1957 that they were allowed the title 'minister'. ${ }^{22}$

Although the modern Methodist Church did not accept women as ordained ministers until I973, both the Primitive Methodist Church and the Bible Christian Church had women itinerants performing all the acts of Christian ministry for many years during the nineteenth century. ${ }^{23}$

19 The joint ministries of Constance and Claud Coltman were at the King's Weigh House Church, London; Cowley Road Congregational Church, Oxford; Wolverton Congregarional Church, and Old Independent Congregational Church, Haverhill.

20 A. Maude Royden, The Church and Woman (London, 1924), p. 195.

${ }^{21}$ In 1987 there were more than 200 women ministers in the United Reformed Church.

$22 \mathrm{~J}$. Briggs, 'She-preachers, widows and other women', in The Baptist Quarterly, 31 (1985-6), PP. 337-52.

${ }^{23}$ See D. Valenze, Prophetic Sons and Daughters (Princeton, 1985) and E. D. Graham, Chosen by Cod: $A$ List of the Female Travelling Preachers of Early Primitive Methodism (Cheshire. 1989). 


\section{ELAINE KAYE}

These pioneers deserve recognition for their loyal service, their creative thinking, and their perseverance amidst much discouragement.

Oxford 